\title{
150 let od narození Leonida Nikolajeviče Andrejeva a Opera slavica
}

Rok 2021 je rokem, ve kterém je vzpomínáno a zmiňováno především 200. výročí narození Fjodora Michajloviče Dostojevského (1821) doprovázené připomenutím i 140. výročí jeho úmrtí (1881). Je to přirozené a odpovídá to významu F. M. Dostojevského, který vešel do světové literatury nejen jako vynikající spisovatel, ale i jako psycholog a filozof, jehož mnohé úvahy jsou i dnes pohř́íchu aktuální a jehož niterně rozervané postavy jako by předjímaly leccos z rozpory zmítaného nitra nás a našich současníků.

V roce 2021 však vzpomínáme i 150. výročí narození dalšího z významných ruských spisovatelů a do jisté míry pokračovatele F. M. Dostojevského: v roce 1871 se narodil Leonid Nikolajevič Andrejev. Vrchol jeho popularity spadá do prvního desetiletí 20. století, kdy Andrejev stejně jako jeho předchůdce dokázal proniknout hluboko do lidského nitra, šokovat otevřeností, s jakou se zmocnil i některých do značné míry „ošemetných“ či ve „vysoké literatuře“ spíše tabuizovaných témat. Jeho povídky, dramata i romány patří do ruské a evropské literatury proto, že reflektují dramatické změny v sebepojetí jedince i v náhledu na nejistoty v sociálním bytí, přičemž se v nich objevují už preexpresionistické a preexistencialistické prvky. Třebaže je Andrejevova dramatická a prozaická tvorba relativně dobře zmapována, přesto lze nalézt lakuny, které by si zasluhovaly větší pozornosti badatelů. Týká se to především Andrejevových románů a jeho publicistiky.

Dovolujeme si tedy prostřednictvím příspěvků uveřejňovaných v čísle 1/2021 Opera slavica připomenout Andrejevovo výročí a možná i maličko povzbudit zájem o studium jeho tvorby.

$-j d-$

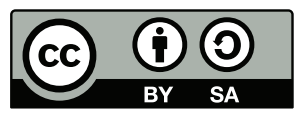

Toto dílo lze užít v souladu s licenčními podmínkami Creative Commons BY-SA 4.0 International (<https:// creativecommons.org/licenses/by-sa/4.0/legalcode>). Uvedenése nevztahuje na díla či prvky (např. obrazovou či fotografickou dokumentaci), které jsou v díle užity na základě smluvní licence nebo výjimky či omezení príslušných práv. 
